ment and the organizers, one representative of each country thanking in his own language the staff and all the people collaborating in the success of the course. In reply, Prof. de Duve thanked all the participants for their cooperation and expressed his satisfaction with the result of this first summer school ; he expressed the conviction that this would be the starting point for a series of similar courses for which interest was amply evident.

The Federation of European Biochemical Societies is to be congratulated on organizing courses of such quality.
The general nature of this kind of course will ensure its future success, and there is clearly no shortage of subjects. The importance of ensuring conditions that will facilitate free international co-operation and interchange in any field of scientific endeavour is not small, and the organization of this course is an important new landmark in the development of relations among scientists of different countries. We are sure that in the very near future similar meetings will be held in other biochemical institutes.

\title{
BIOCHEMISTRY IN MAGDEBURG
}

$\mathrm{W}$ E have recently returned from a short visit to East Germany, where we were invited, as guests of the G.D.R. Government, to participate in the second annual conference of the Biochemical Section of the Society for Experimental Medicine of the G.D.R. held at Magdeburg during June 24-26.

The conference was held at the Medical Academy in Magdeburg under the presidency of Prof. K. Lohmann. It was attended by about 300 biochemists, including a notable group from the Federal Republic of Germany and representatives of many countries of Eastern and Western Europe. Prof. Eberhard Hofmann, of Magdeburg, in his organization of the conference, followed the best traditions of international scientific meetings.

The meeting centred about three symposia: (a) "Functional Biochemistry of Cell Membranes and Mitochondria"; (b) "Problems of the Regulation of Glycolysis and Fermentation"; (c) "Aspects of the Training of Biochemists". There were also sessions where short communications were read. In all, about 100 papers wer $\Theta$ heard.

By far the most interesting event was the symposium on glycolysis and fermentation. This session, conducted admirably by Prof. H. Frunder, of Jena, was introduced by Prof. Benno Hess, Dortmund. In his exposition, Hess centred his arguments on mathematical models of glycolysis and on the oscillatory behaviour of metabolites under transitional conditions in living yeast and in yeast press juice. The importance of phosphofructokinase in regulatory mechanisms was emphasized in many contributions. Thus Hommes (Nijmegen) described a number of phosphofructokinases in different yeasts which were all inhibited by ATP. The phosphofructokinases from yeasts that showed an aperiodic change in pyridine nucleotide levels after anaerobiosis were activated by fructose-6-phosphate and not by AMP, while the enzymes from 'asymptotic' yeasts were activated by neither of these compounds. 'Oscillatory' yeasts had phosphofructokinases which were inhibited by ATP and activated by fructose-6-phosphate and AMP. Freyer and Kopperschläger (Magdeburg) suggested that the high aerobic glycolysis of ascites tumour cells could be explained by the insensitivity to ATP of the phosphofructokinase, together with the low pyruvate utilization and the limited power of the mitochondria to oxidize cytoplasmic NADH. The inhibition of glycolysis in ascites tumour cells by alkylating cytostatic agents appears to be due to an activation of NAD-splitting enzymes (Grunicke, Richter and Holzer, Freiburg). Lamprecht (Munich) discussed the regulation of glycolysis in human heart muscle. Rapoport (Berlin) considered the regulatory significance in erythrocytes of an NADP-dependent lactate dehydrogenase and, in ascites tumour cells, of a lactate oxidase not requiring a pyridine nucleotide.

In the symposium on the training of biochemists, we learned from Prof. Hofmann's introductory remarks that courses for biochemists in the Faculty of Science existed. in only two German universities: Tübingen in the West and the Humboldt University in East Berlin. Hofmann emphasized the need for additional courses of this kind. We had the opportunity of describing the existing courses in London and some of the proposed developments in Britain's now universities. Prof. Bücher (Munich) expressed enthusiasm for the relative brevity of degree courses in Britain and was joined by Prof. Rapoport (Humboldt University, Berlin) in a plea for the elimination of the time-consuming medical course as a prerequisite for a biochemical career in Germany. It was evident that these matters were of vital interest to the younger members of the conference.

We were impressed by the high quality of the scientific work as it was described in the communications and by the evident desire of our East German colleagues to improve their contacts with the countries of the West. It is deeply disturbing that the absurdities of politics make it difficult for us to contribute to this improvement and to make a full return for the hospitality which wo received.

D. F. Cheesman J. R. LAgNado

\section{INDUSTRIAL FEEDING AND CANTEEN MANAGEMENT}

\begin{abstract}
THE report on the joint symposium on "Industrial Feeding and Canteen Management in Europe", held in Rome during September 2-7, 1963, has now been published under the auspices of the Food and Agriculture Organization, the International Labour Organization, and the World Health Organization*. After explaining the reasons for the interest of these organizations in the subject, the report summarizes the situation to-day in various European countries and suggests some steps to

* Food and Agriculture Organization of the United Nations. FAO Nutrition Meetings Report Series, No. 36: Report of the Joint Symposium on Industrial Feeding and Canteen Management in Europe, Rome, Italy, 2-7 September, 1963. Pp. 44. (Rome: Food and Agriculture Organization of the United Natilins. London: H.M.S.O., 1965.) 2s. $6 d . ; 50$ cents.
\end{abstract}

be taken if these specialized agencies are to assist member countries to solve their more urgent problems.

In most European countries industrial feeding is regarded as an integral part of the facilities of the factory, even though the provision of food to workers is frequently not required by law. The determining factor in provision of a canteen and in the type of service offered is usually the demand and need of the workers. The use of canteen services varies in different countries and is often disappointingly small. The effect of nutrition on occupational health and on working efficiency and such matters as food supply, levels of food consumption and food habits, as well as the problems encountered in pro- 